\title{
Discoverers of the Galvanic Skin Response
}

Key words: galvanic skin response, electrodermal activity, Féré, Tarchanoff

\section{Galvanic Skin Response and its role in the instrumental detection of deception}

The GSR (galvanic skin response, or electrodermal activity) channel is considered the most diagnostic recording in polygraph examinations, and the best discriminator between people providing deceptive answers to test questions and non-deceptive subjects.

Slowik and Buckley as well as Widacki note that several laboratory studies and experiments in which students played subjects in fictitious crime situations indicated that the galvanic skin response is the most reliable indicator of deception (Slowik \& Buckley 1975, Widacki 1977), even though at this time many polygraph examiners with experience in real-life examinations stated that the most reliable indicator of deception is respiration. The GSR is a better indicator in experimental cases as

\footnotetext{
*jan.widacki@gmail.com
} 
well as in the card test (Reid \& Inbau 1966: 256). Yet in the next edition of their book, Reid and Inbau admitted that the GSR is the best indicator in POT and in the Silent Answer Test (SAT) (Reid \& Inbau 1977: 287-278). In an ingenious study conducted by Slowik and Buckley cited above consisting of 30 cases, the examiners asked in 'blind interpretation' and identified deception with an average accuracy of $87.2 \%$ when all three physiological indicators (respiration, GSR, cardio) were analysed. When they based their opinion on respiration alone, the accuracy dropped to $80.5 \%$, to $80.0 \%$ when relying on GSR alone, and to $77.1 \%$ when working with blood pressure results alone. Thus the results based on the GSR (80.0\%) and on respiration $(80.5 \%)$ were almost the same in a relatively small group (30 people).

In the material covering 36 cases of polygraph examinations conducted in criminal cases in the Department of Criminalistics of the University of Silesia in the late 1970s, whose results were corroborated with valid final court judgements, reactions considered symptomatic were in most cases recorded on the GSR channel. Reactions on that channel were present after critical questions in nearly $70 \%$ of cases, while reactions of this type were present on the respiration record in only $51 \%$ of cases, and on the cardiovascular record - in only $44 \%$ of cases (Widacki 1982: 61, 64).

Similarly, studies of Raskin and collaborators suggested GSR as the most effective parameter (Raskin et al. 1978). For objectivity's sake, it should be noted that some authors find GSR the least effective parameter (see: Matte \& Reuss 1989, 1992). Franz, who resorted to a computer analysis of 100 confirmed field cases, found the electrodermal response to be the most accurate (Franz 1990). According to another author, R. Ryan (Ryan 1989), the GSR is most effective in identifying the deceptive ('guilty') subject but it is respiration that allows one to identify the non-deceptive ('innocent') subjects most effectively.

In the polygraph examination techniques most frequently applied in recent times, for example, the Utah Zone Comparison Technique (UZCT) in the numerical assessment of the recordings, as for example Empirical Scoring System (ESS) the diagnostic value of the GSR is assessed much higher than respiratory symptoms (Krapohl, Shaw 2015).

Changes in the GSR are the most frequently used indicator in various simplified lie detection procedures. One of them makes use of a new device introduced by the Americans in Afghanistan and Iraq for the initial screening of suspects. It is the socalled Preliminary Credibility Assessment Screening System: (PCASS). The PCASS is a handheld computer or personal digital assistant that attempts to measure stress to decide whether a subject is telling the truth. To detect deception, the PCASS uses 
external physiological information (GSR and cardiovascular) collected during an interview with a photoplethysmograph (Gordon, Fleisher 2011: 321).

Thus changes in the GSR are still used both for classical polygraph examinations, and for a variety of simplified procedures of instrumental lie detection based on the observation of physiological correlates of emotion.

It is worth to mention that much of experimental research on the detection of deception makes use of a psychogalvanometer alone rather than of a multi-channel polygraph device. For example, David Lykken's first experiments (Lykken, 1959) which gave rise to the Guilty Knowledge Test (GKT) only made use of a psychogalvanometer and not of a polygraph.

\section{Galvanic Skin Response: a short history of discovery}

In 1849, Emil du Bois-Reymond in Germany discovered that the human skin is electrically active. In the later years of the 19th century, Romain Vigouroux, a collaborator of the French neurologist Jean Charcot (1825-1893), measured tonic skin resistance levels in various emotionally distressed patient groups when looking for clinical diagnostic signs during studies of hysteria and hypnosis in Charcot's laboratory. He noticed that the electrical resistance of the skin increases on the sedated part of the body of his hysteric patients (Vigouroux 1879).

In the same laboratory, Charles Féré (1852-1907) found that by passing a low electrical current between two electrodes placed on the surface on the skin, one could use a galvanometer to measure momentary decreases in skin resistance in response to a variety of stimuli of various types, including visual and auditory ones (Féré 1888). In this way Fére discovered that the skin becomes a better conductor of electricity in the presence of external stimuli.

In 1890, a Russian physiologist of Georgian origin, Ivan Tarchanoff (Tarchanov, Tarkhanishvili, 1846-1908) discovered that one could measure changes in the electrical potential between two electrodes placed on the surface of the skin, yet unlike in Férés experiment, without applying an external source of current. Various stimuli result in a change in the electrical potential and make the pointer of the galvanometer move (Tarchanoff 1890).

As Jaffres proved, the Féré phenomenon and Tarchanoff phenomenon have same physiological mechanism and are two ways of observing and measuring the same phenomenon (Jeffres 1928). 
Thus Féré and Tarchanoff are the joint discoverers of the galvanic skin response.

It is thanks to these two scientists that we can resort to galvanic skin responses in contemporary instrumental lie detection.

In 1897, a German, Georg Sticker, was the first to suggest the use of a galvanometer (psychogalvanometer) for lie-detection (Trovillo 1939), and in 1909 Otto Veraguth used electrodermal response for his experiments with word association. More than 85 years ago, John Larson complemented what had previously been a two-channel polygraph with the psychogalvanometer. Since then a psychogalvanometer has been a significant and standard component of all polygraph devices (Abrams 1989: 4), while the Galvanic Skin Response (GSR) is among the prime and most evident and accurate physiological changes used in instrumental detection of deception.

It is generally assumed that the United States is home to the polygraph. Even at the most recent, 50th Seminar of the American Polygraph Association in Chicago, held from 30 August to 4 September 2015, Frank Horvath and Stanley Slowik, in a paper delivered under the title of "The Birthplace of Modern Polygraphy", tried to convince the audience that the actual birthplace is Chicago. It is true that the United States is the country where the contemporary polygraph was constructed, and which also boasts the longest practice in the use of the machine which began in the 1920s. However, it goes without saying that polygraph examination has European roots. Without these, as well as without European experimental psychology and without the European discoveries in physiology and psychophysiology of the late 19th and early 20th centuries, without European scientists who in some cases (notably Hugo Münsterberg) were also active in the United States, the origin and development of polygraph examinations would not have been feasible. In a nutshell, without European scholars of the order of Angelo Mosso, Vittorio Benussi, Cesare Lombroso, Charles Féré, and Ivan Tarchanoff, the works of John Larson and Leonard Keeler, whom Americans rightly consider to be the 'fathers of the polygraph examination, would not have been possible (Widacki 2012).

\section{Discoverers}

Charles Samson Féré was born in July 1852 and died on 22 April 1907. He was a French physician, whose broad range of scientific interests encompassed medicine, psychology, physiology, sexology, and the phenomena of magnetism and hypnosis. In relation to the last of these topics he collaborated with Alfred Binet, the later inventor of a method for practical measurement of intelligence. To a certain extent 
he was also involved in criminology to which he contributed the seminal works: Degeneration and criminality (Dégénérescence et criminalité) published in 1888 and La Famille névropathique (The neuropathic family), published in 1894. From 1881 Féré was an assistant to Jean-Martin Charcot (1825-1893). As mentioned above, R. Vigouroux also worked with M. Charcot.

In 1888, Féré published a short report entitled Note sur les modifications de la résistance électrique sous l'influence des excitations sensorielles et des émotions (A note on changes in electrical resistance under the impact of sensory stimulation and emotion) in the journal Comptes rendus des séances de la Société de biologie (Ser. 9, 40, 5, pp. 217-219).

As mentioned above, in his experiment, Féré attached two electrodes connected in series to a weak source of electricity and to a galvanometer to the forearm of the patient whom he later subjected to a range of sonic, olfactory, and visual stimuli. Such stimuli had the galvanometer pointer moving. Initially, Féré believed this to be the result of friction on dry skin. Yet Jaques-Arsene d'Arsonval (1851-1940), a physicist he collaborated with, realised that the change in conductivity was linked to sweating (d'Arsonval 1888). Thus, what we refer today as the 'Féré phenomenon' should more properly and justly be called 'the phenomenon of Féré - d'Arsonval.

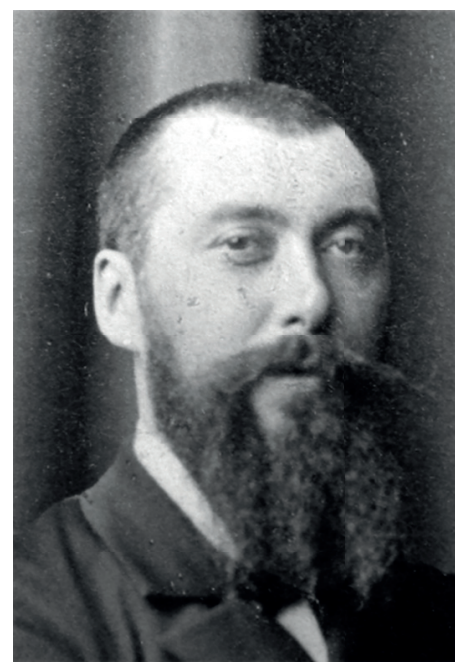

Fig. 1. Ch.S. Féré

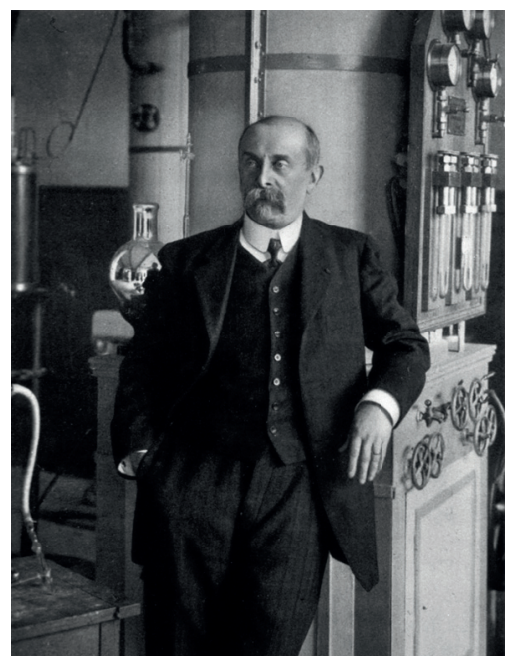

Fig. 2. J.A. d'Arsonval

In his publication from 1890, Ivan Tarchanoff presents the discovery that the galvanometer reacts similarly to stimuli even in the absence of an external source of energy (Tarchanoff 1890). The scientist attached electrodes to two randomly chosen points 
on the skin of the patient and, by placing a galvanometer between them, proved a difference in potential between the points. When he subjected the patient to such stimuli as Féré did, the electric potential changed, resulting in the movement of the galvanometer. This phenomenon is known as the 'Tarchanoff phenomenon'.

Both the methods - that of Féré using only an external source of electricity and that of Tarchanoff using solely the endosomatic electrical potential - study and observe the same phenomenon and the same physiological mechanism (Jeffers 1928). For this reason, we can speak of 'the Féré - Tarchanoff phenomenon' being used in polygraph examinations. Today, thanks to the experiments of Darrow from the 1930s, we know that it doesn't use the changes in skin wetness caused by sweating, as the response in the form of a change in conductivity comes before sweat, but from the action of the sweat glands themselves.

Ivan Tarchanoff (born Ivane Tarchan Mauravov Tarkhnishvili), in fact the only East European academic with a significant contribution to the scientific foundations for polygraph examinations, is moreover an exceedingly interesting figure. He was a great scholar of European format, symbolically combining the nations of Central and Eastern Europe. A Georgian aristocrat, a graduate of a Russian university and later a member of the Russian faculty, a professor of the Military Medico-Surgical Academy in Saint Petersburg, he was an avid experimenter in what is broadly construed as physiology and a promoter of science.

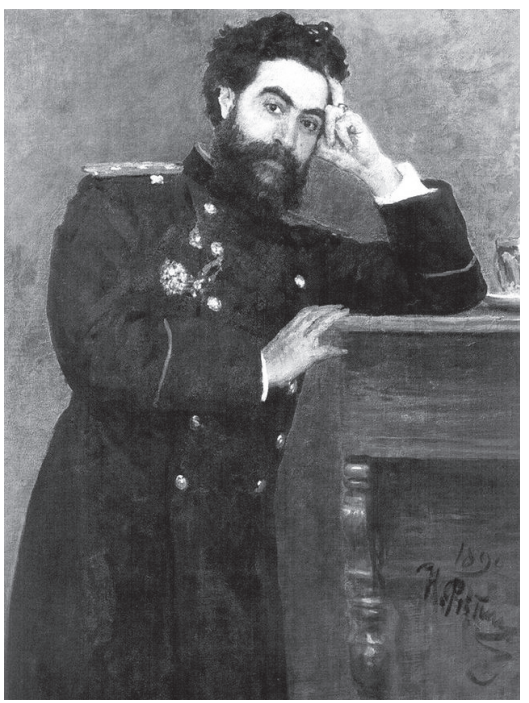

Fig. 3. I. Tarchanoff as professor of the Imperial Miltary Medico-Surgical Academy (by I. Repin) 
Known for his progressive and liberal views, Tarchanoff could not win favour among the Russian authorities. There are reasons to believe that it was under their pressure that he was forced to leave his academic chair at the age of 48, in 1894. Still popular in Russia and portrayed by the best Russian painters, notably Ilia Repin he was also popular in Western Europe and among Polish scientific and cultural circles. Tarchanoff popular lectures in Saint Petersburg received coverage even in the Polish daily press. He published in the best West European scientific magazines, and participated in numerous international congresses. His ties to Poland were especially strong. He married a Jew from Vilnius (Polish: Wilno), Elena (Helena) Antokolska, an artist sculptor brought up in the Polish culture. Moreover the Russian academic was a teacher and friend of Napoleon Cybulski whom he successfully recommended as his assistant in Saint Petersburg to the Chair of Physiology of the Jagiellonian University in Kraków. Later Dean of the Medical Faculty and Rector of the Jagiellonian University, Cybulski was among the greatest Polish academics of the turn of the 19th and early 20th centuries, co-discoverer of adrenaline, and one of the first in the world to have obtained a recording of the electrical changes in the cortex of the brain (Widacki 2015), and he is recognised as the creator of the Polish school of physiology.

The fact that in 1905 Tarchanoff arrived in Kraków, at that time part of Austrian Galicia, most probably with the intention of settling in the vicinity of the city for good, is hardly known to Tarchanoff's biographers and researchers of his work (Tsagareli 2012). He made his home near Kraków, in Nawojowa Góra, and had Napoleon Cybulski as a neighbour.

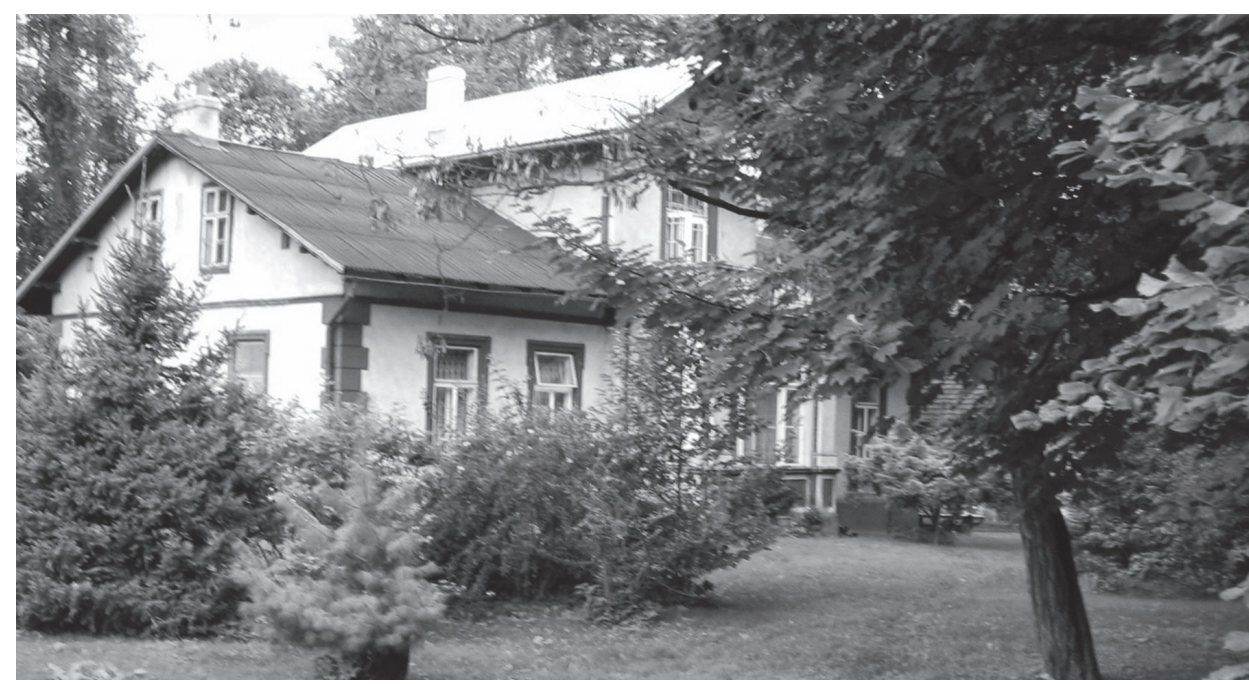

Fig. 4. Tarchanoff's house in Nawojowa Góra (Poland) 
Tarchanoff published his last works in cooperation with Cybulski in Kraków in Galicia in 1905-08. The Annual of the Academy of Arts and Sciences in Kraków (1905/1906) recorded that the Faculty of Mathematics and Natural Sciences 'at its sessions analysed 75 works, of which it approved 71 for publication' (Rocznik 1906: 83), of which 13 related to botany, and their number included a preliminary report from Professor Tarchanoff entitled "observations on the radioactive properties of plants" (Rocznik 1905/1906: 85)'. The article was finally published in the French version of the Bulletin of the Academy of Art and Sciences, with I. Moldenhauer as co-author. In 1907, Cybulski and Tarchanoff together published an article in Polish entitled 'Kilka słów w sprawie jadów w jelicie prawidłowym' (A few words on toxins in healthy intestine). The article was published in Lemberg (Polish Lwów) in the Polish language in a medical journal Tygodnik Lekarski (Cybulski, Tarchanoff 1907). It was probably Trakhanoff's last publication as he died in his home in Nawojowa Góra near Kraków on 24 August 1908 (Nawojowa Góra belongs to Rudawa parish).

It is intriguing to note that, according some sources, e.g. the Great Soviet Encyclopedia and even Wikipedia, Tarkhanow died in Saint Petersburg (Great Soviet Encyclopedia [Bolshaya sovetskaya entsiklopediya 1976, Wikipedia as visited in 2014).

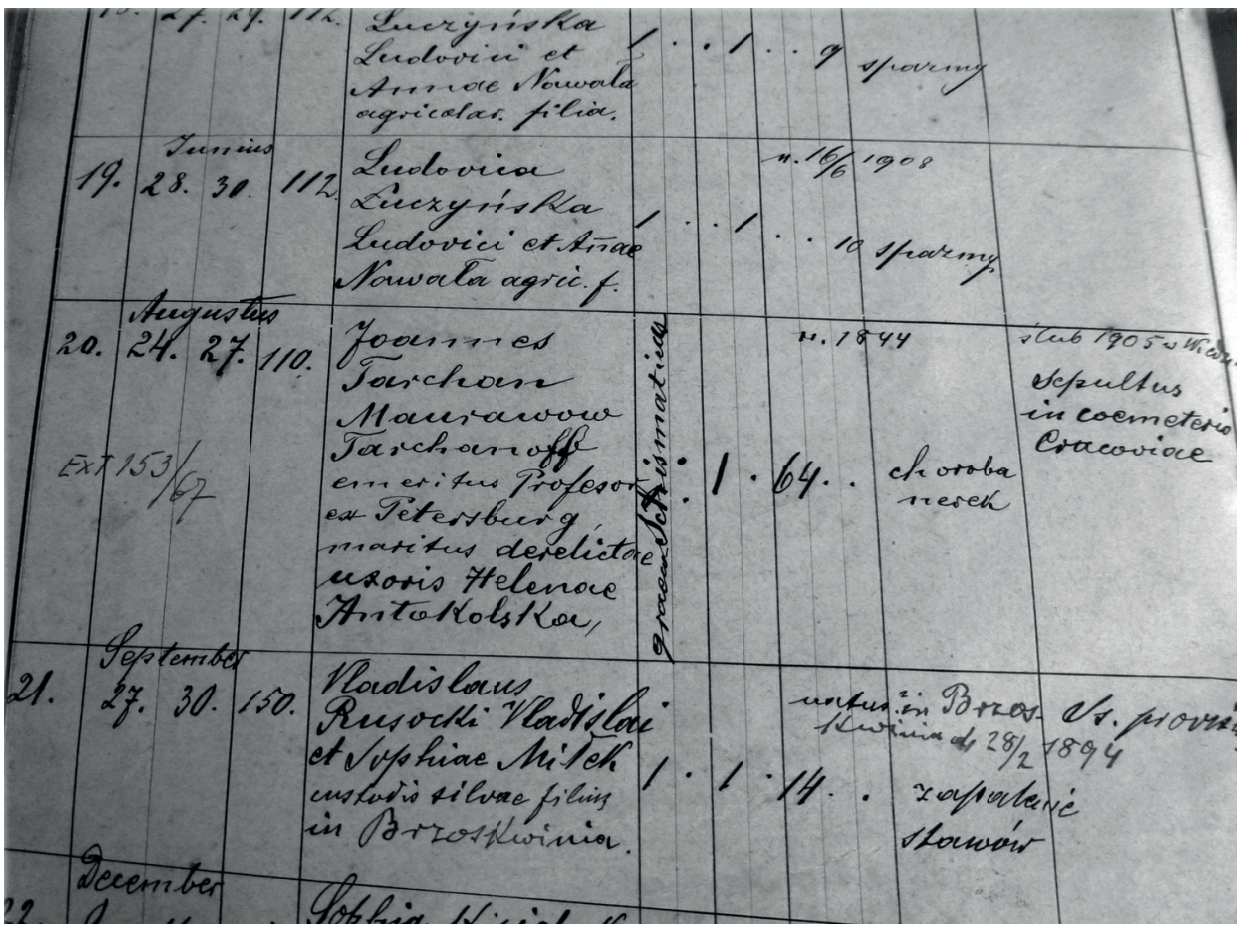

Fig. 5. Rudawa parish register "Liber Mortuorum" (attesting to Tarchanoffs death) 
After his death in 1908, Tarchanoff was first temporarily buried in a Kraków cemetery, yet his body was moved to Saint Petersburg where it was finally interred in the cemetery by the Alexander Nevsky Lavra.

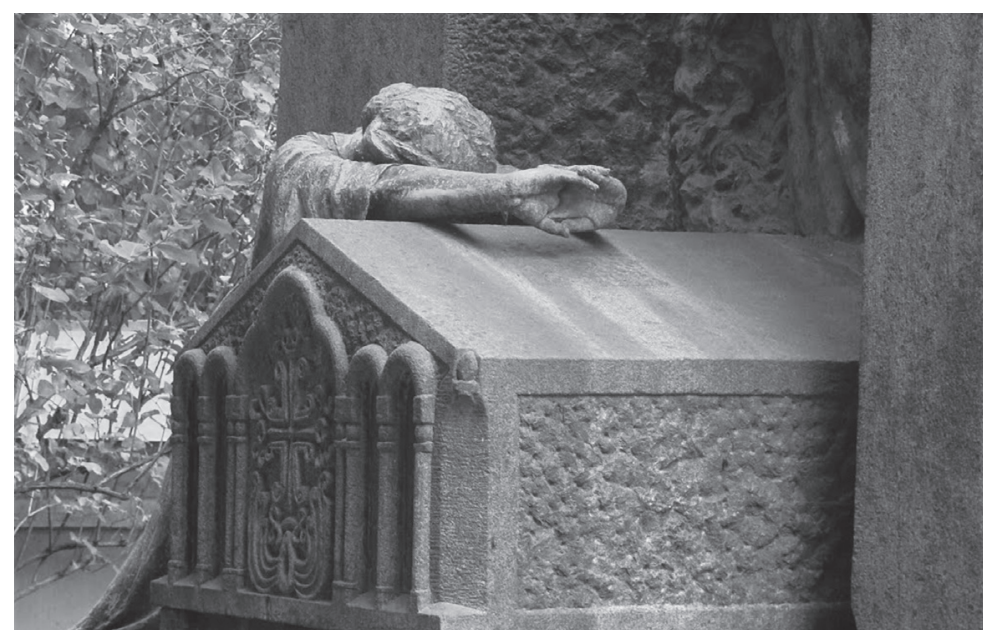

Fig. 6. Tarchanoff's grave in Petersburg

A monument to Ivan Tarchanoff can be found in Tbilisi, on the front of the main building of the Medical University. This is how a co-discoverer of the galvanic skin response symbolically brought together Russians, Georgians, and Poles.

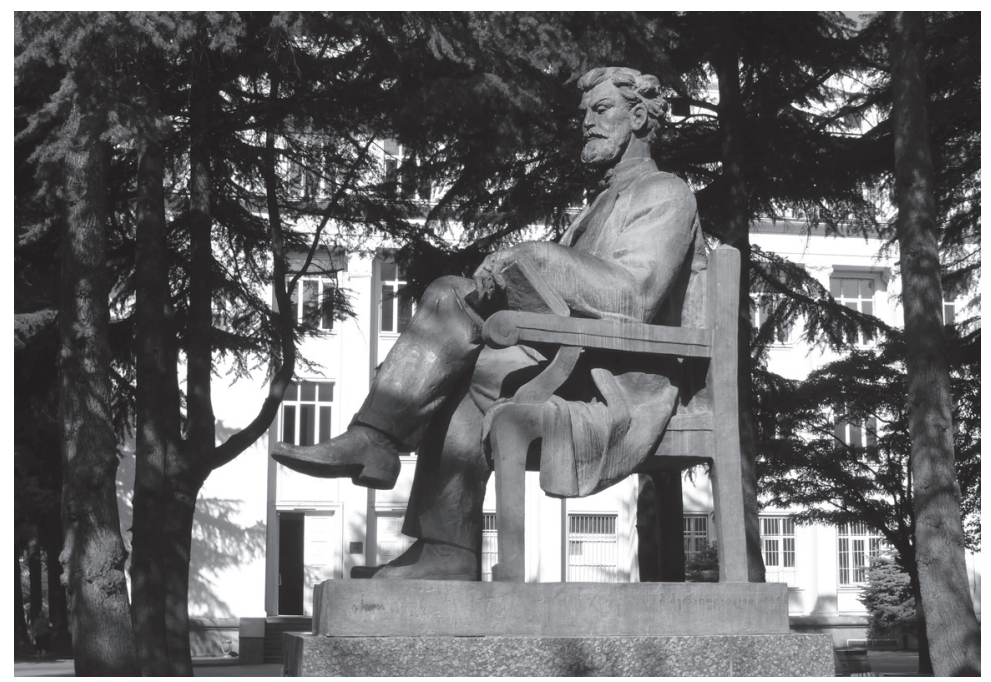

Fig. 7. Monument to Tarchanoff in Tbilisi 


\section{References:}

Abrams S. (1989): The complete polygraph handbook, Lexington Books, Lexington, Mass., Toronto.

D’Arsonval A. (1888): Remarques a'propos de la production d'electricite chez l'homme, Comptes Rendus Societe de Biologie, 40, 142-144.

Cybulski N., Tarchanow I. (1907): Kilka słów w sprawie jadów w jelicie prawidłowym, Lwowski Tygodnik Lekarski, 2 (41), 579-580.

Bolshaya sovetskaya entsiklopediya (1976): A.M. Prochorow ed., Vol. 25, 3rd edition, Moscow, p. 387. Féré Ch. (1888): Note sur les modifications de la resistance electrique sous l'influence des excitations sensoriells et emotions, Comptes Rendus Societe de Biologie, 40, 217-219.

Franz M.L. (1990): Technical report: relative contributions of physiological recordings to detect deception, DoD contract MDA 904-88-M-6612 Argenbright Polygraph, Inc. Atlanta GA.

Gordon N.J., Fleisher W.L. (2011): Effective interviewing and interrogation techniques, 3rd ed., Elsevier, Academic Press, Amsterdam, Boston, Heidelberg, London, New York, Oxford, Paris, San Diego, San Francisco, Sydney, Tokyo.

Jeffres L.A. (1928) Galvanic phenomena of the skin, Journal of Experimental Psychology, 11 (2), 130-144.

Krapohl D., Shaw P. (2015): Fundamentals of polygraph practice, Elsevier, Academic Press, Amsterdam, Boston, Heidelberg, London, New York, Oxford, Paris, San Diego, San Francisco, Sydney, Tokyo.

Lykken D.T. (1959): The GSR in detection of guilt, Journal of Abnormal and Social Psychology, 43, 6.

Matte J.A., Reuss R.M. (1989): A field validation study of the Quadri-Zone Comparison Technique, Polygraph, 18 (4), 187-202.

Matte J.A., Reuss R.M. (1992): A study of the relative effectiveness of physiological data in field polygraph examination, Polygraph, 21 (1), 1-22.

Raskin D.C., Barland G.H, Podlesny J.A. (1978): Validity and reliability of detection of deception, Washington D.C. National Institute of Law Enforcement and Criminal Justice. 
Reid J., Inbau F. (1966): Truth and deception. The polygraph (lie-detection) technique, The Williams \& Wilkins Comp., Baltimore.

Reid J. Inabu F. (1977): Truth and Deception. The polygraph (lie-detector) technique, 2nd ed., The Williams \& Wilkins Comp., Baltimore.

Ryan R. (1992): Relative validity and utility of examiner diagnosis of truth and deception utilizing respiration, cardiovascular, and galvanic skin response, unpubl. Master's thesis, Reid College of Detection of Deception (quoted from: J.A. Matte: Forensic psychophysiology - using the polygraph, J.A.M. Publications, Williamsville, New York.

Slowik S., Buckley J.P. (1975): Relative accuracy of polygraph examiner diagnosis of respiration, blood pressure and GSR recordings, Journal of Police Science and Administration, 3 (3), 305-310.

Tarchanoff I. (1890): Über die die galvanischen Erscheinungen in der Haut des Menschen bei Reizungen der Sinnesorgane und bei verschiedenen Formen der psychischen Thätigkeit, Pflüg. Arch. Ges. Phys., 46, 46-55.

Tarchanow I., Moldenhauer T. (1906): Promienistość indukowana i naturalna roślin i jej prawdopodobne znaczenie dla wzrostu roślin, Bulletinn Internationale de l'Academie des Sciences de Cracovie Anne 1905, Classe des Sciences mathematiques et Naturelles, 393-408.

Trovillo P.V. (1939): A history of lie-detection, The Journal of Criminal Law and Criminology, 29.

Tsagareli M.G. (2012): Ivane Tarkhanishvili (Tarchanoff). Major Georgian Figure from Russian Physiological School, Journal of the History of Neuroscience, 21, 393-408.

Vigouroux R. (1879): Sur le role de la resistance electrique des tissus dans le'electrostatic, Comptes Rendus Societe de Biologie (Series 6), 31, 336-339.

Widacki J. (1977): Wartość diagnostyczna badania poligraficznego i jej znaczenie kryminalistyczne, Wydawnictwo UJ, Kraków.

Widacki J. (1982): Analiza przesłanek diagnozowania w badaniach poligraficznych, Wydawnictwo Uniwersytetu Śląskiego, Katowice.

Widacki J. (2012): European roots of instrumental lie-detection, European Polygraph, 6, 4 (22). 
Widacki J. (2015 a): Profesor Iwan Tarchanow, Przegląd Lekarski, 72/1.

Widacki J. (2015 b): Ivane Tarkhnishvili (Ivan Tarchanoff) and his links with Poland, Journal of the History of Neurosciences, 4, 1-9.

Wikipedia, https://en.wikipedia.org/wiki/Ivan_Tarkhanov_\%28physiologist\%29 [accessed on 05.07.2014].

The article is a part of Polish National Science Centre's (NCN) project no. DEC-2013/11/B/ H55/03856 